\title{
Kvaliteten på kvalitativ forskning
}

Det stilles like høye krav til kvaliteten på kvalitative studier som på kvantitative studier.

\section{Forfatter}

Marit Leegaard

Professor

Institutt for sykepleie og helsefremmende arbeid, Oslomet - storbyuniversitetet

kvalitativ metode

Forskningskvalitet

Sjekkliste

Sykepleien Forskning 2019 14(53932)(e-53932)

DOI: https://doi.org/10.4220/Sykepleienf.2019.53932

I Sykepleien Forskning har over halvparten av de manuskriptene vi mottar til vurdering, brukt et kvalitativt design. En mulig forklaring er at kvalitative forskningsmetoder appellerer til et fag som sykepleie siden disse metodene gir bedre mulighet til å svare på forskningsspørsmål om erfaringer, prosesser og mening.

En mer pragmatisk forklaring kan være at kvalitative metoder fremstår som enklere, og derfor eksisterer det myter om at de er mindre krevende å gjennomføre. Målet med denne artikkelen er å vise at vi stiller like høye krav til kvalitet på kvalitative studier som på kvantitative, men at fokuset er ulikt.

\section{Sjekklister}


Til tross for mye arbeid de siste tretti årene med å sikre kvalitet er det ingen internasjonal konsensus på hva som karakteriserer kvalitet på kvalitativ forskning. Sjekklister som har blitt utviklet og stadig mer brukt, tillater forskere å hevde at de har sjekket kvaliteten på studien uten at de faktisk har gått inn og løst de problemene disse instrumentene har avslørt (1).

Eksempler på slike problemer er for lite beskrivelse av hvilken logikk som ligger til grunn for de funnene som blir presentert, og sammenblanding av metodekrav med de metodene som faktisk er brukt. Det essensielle er om de vurderingene som er gjort i hver kvalitative studie, er transparente og forståelige for andre forskere og lesere av den forskningsartikkelen som beskriver studiens funn.

\section{Evaluering}

Det er publisert mange artikler om hvorfor og hvordan vi skal evaluere kvaliteten på kvalitativ forskning. Kvalitet blir ofte beskrevet med begreper som transparens, troverdighet, pålitelighet og gyldighet.

Her i Sykepleien Forskning har vi anbefalt kvalitative forskere å anvende Consolidated criteria for reporting qualitative research (COREQ): a 32-item checklist for interviews and focus groups før de sender inn manus (2). Det er imidlertid utarbeidet flere ulike sjekklister eller instrumenter som kan brukes for å vurdere kvaliteten på kvalitativ forskning (3-6).

Her følger en sjekkliste (6) som kan være enklere i bruk enn COREQ, og jeg anbefaler den som et nyttig hjelpemiddel til fremtidige forfattere og fagfeller i Sykepleien Forskning.

\section{Sjekkliste for kritisk vurdering av kvalitativ forskning}

Det er tre hovedområder som bør bli vurdert når vi

skal evaluere kvalitative forskningsfunn: 
- Hva er funnene?

- Er funnene gyldige?

- Er funnene klinisk relevante?

Her presenterer jeg en sjekkliste med ti spørsmål som kan bidra til å finne svar på de tre hovedområdene på en systematisk måte (6). Sjekklisten kan brukes av forskere når de planlegger å gjøre en kvalitativ studie, eller som et instrument for kritisk å vurdere en kvalitativ forskningsartikkel.

De to første spørsmålene er en grunnleggende kartlegging av om dette er en studie det er verdt å evaluere. Disse spørsmålene bør du også ha et klart svar på i den prosjektplanen som ligger til grunn for forskningen.

\section{Er målene med studien tydelige?}

$\square$ Ja $\square$ Usikker $\square$ Nei

Vurder:

- Hva er målet med studien?

- Hvorfor er studien viktig?

- Relevans for studien

2. Er det hensiktsmessige å bruke kvalitativ metode?

Ja $\square$ Usikker $\square$ Nei

Vurder:

- Om studien prøver å tolke eller belyse handlinger og/eller subjektive opplevelser fra forskningsdeltakere

- Om kvalitativ forskning er riktig metode for å besvare forskningsspørsmålene

Er det noen vits å fortsette? 
Hvis du har svart tydelig ja på begge spørsmålene, kan du gå videre. Hvis ikke bør du tenke nøye gjennom hva som bør endres med studien før den blir satt i gang. Hvis studien er gjennomført og du skal være fagfelle, kan det være at studien ikke skal bli publisert.

3. Er forskningsdesignet hensiktsmessig for å nå målene med studien?

$\square$ Ja $\square$ Usikker $\square$ Nei

Vurder:

- Om forsker(ne) har begrunnet valg av forskningsdesign

- Om forsker(ne) har diskutert hvorfor de landet på en bestemt kvalitativ metode, for eksempel intervju eller fokusgruppe

4. Var rekrutteringsstrategien hensiktsmessig for studiens mål?

Ja $\square$ Usikker $\square$ Nei

Vurder:

- Har forsker(ne) beskrevet hvordan deltakerne ble rekruttert?

- Har forsker(ne) beskrevet hvorfor deltakerne de valgte, var de mest hensiktsmessige for å gi tilgang til den typen av kunnskap som etterspørres i studien?

5. Er datainnsamlingen hensiktsmessig for studiens tema?

Ja $\square$ Usikker $\square$ Nei

Vurder:

- Om forsker(ne) begrunner hvor data blir samlet inn

- Om det er klart hvordan data blir samlet inn, eksempelvis gjennom fokusgrupper eller semistrukturerte intervjuer 
- Har forsker(ne) begrunnet valg av metode for datainnsamling?

- Har forsker(ne) utdypet metodene, for eksempel hvordan intervjuene ble gjennomført? Ble det brukt en intervjuguide?

- Om metodene ble endret underveis i studien, har forsker(ne) forklart hvordan og hvorfor?

- Er typer av data klart beskrevet, for eksempel båndopptak, videofilming eller notater?

- Har forsker(ne) diskutert metning av data?

6. Har forholdet mellom forsker(e) og deltakere blitt vurdert tilstrekkelig?

$\square$ Ja $\square$ Usikker $\square$ Nei

Vurder:

- Har fforsker(ne) vært kritiske til sin egen rolle med mulige feil og påvirkning når a) forskningsspørsmålene ble formulert, og b) under datainnsamling (inkludert rekruttering og valg av sted)?

- Har forsker(ne) reflektert over hendelser i løpet av studien og om det ble vurdert å endre på elementer i forskningsdesignet?

\section{Har etiske spørsmål ved studien blitt vurdert?}

$\square$ Ja $\square$ Usikker $\square$ Nei

Vurder:

- Beskriver forsker(ne) nok detaljer om hvordan studien ble forklart for deltakerne så leseren av artikkelen (eller prosjektplanen) kan vurdere om etiske retningslinjer blir fulgt?

- Diskuterer forsker(ne) etiske spørsmål ved egen studie, som for eksempel informert samtykke, konfidensialitet eller hvordan forskerne håndterte effekten studien hadde på deltakerne under eller etter avsluttet studie? 
- Er det søkt om godkjenning fra en etisk komité?

\section{Er dataanalysen nøyaktig nok?}

$\square$ Ja $\square$ Usikker $\square$ Nei

Vurder:

- Er det en detaljert forklaring av analyseprosessen?

- Hvis tematisk analyse: Kommer det klart frem hvordan kategorier/temaer ble utledet fra den transkriberte teksten?

- Forklarer forsker(ne) hvordan presenterte data ble valgt ut fra det originale transkriptet for å demonstrere hvordan data er analysert?

- Presenteres det tilstrekkelig med data for å understøtte funn?

- Er det tatt hensyn til motstridende data?

- Har forsker(ne) kritisk vurdert egen rolle, mulige feil og påvirkning av dataanalysen og valg av hvilke data som blir presentert?

\section{Kommer funnene tydelig frem?}

$\square$ Ja $\square$ Usikker $\square$ Nei

Vurder:

- Om funnene er tydelige

- Om det er en dekkende og adekvat diskusjon av forskning som både støtter og motstrider studiens funn

- Om forsker(ne) diskuterer troverdigheten av egne funn

- Om funn er diskutert i sammenheng med de originale forskningsspørsmålene

10. Er studien viktig?

$\square$ Ja $\square$ Usikker $\square$ Nei

Vurder: 
- Diskuterer forsker(ne) hva som er studiens bidrag til tidligere forskning eller teoretisk kunnskap? Vurderes funn opp mot dagens kliniske praksis?

- Identifiseres nye forskningsområder?

- Diskuterer forsker(ne) om funn kan overføres til andre populasjoner, eller om forskningen kan anvendes på andre områder?

Klikk her for utskriftsvennlig versjon av sjekklisten.

\section{Konklusjon}

Alle sjekklister skal brukes som et råd for hva som er relevant å vurdere, og skal derfor ikke følges slavisk. Gode evner til å kunne bedømme kvaliteten på kvalitativ forskning kritisk krever mer enn en enkel sjekkliste, men listen kan bidra til å gjøre studien mer transparent. Ekspertise krever trening og erfaring og en erkjennelse av at din egen smak alltid vil påvirke alle vurderinger vi gjør.

Smaken beskrives som den dømmekraften som er involvert i all vurdering av hvor verdifull forskningen er, og smak er erkjennelsen av hvordan våre preferanser, følelser og medlemskap i en eller flere smakskulturer får betydning for de vurderingene vi gjør. Et eksempel på smakskultur er kunnskapsbasert praksis og sterke preferanser for standardiserte beskrivelser (1).

Artikkelen er en oppdatering av artikkelen som ble publisert i Forskningens ABC 2017:(2).

\section{Referanser}

1. Sandelowski M. A matter of taste: evaluating the quality of qualitative research. Nursing Inquiry. 2014. DOI: $\underline{10.1111 / \operatorname{nin} .12080}$ 
2. Tong A, Sainsbury P, Craig J. Consolidated criteria for reporting qualitative research (COREQ): a 32-item checklist for interviews and focus groups. International Journal for Quality in Health Care. 2007;19:349-57.

3. Hannes K, Lockwood C, Pearson A. A comparative analysis of three online appraisal instruments' ability to assess validity in qualitative research. Qualitative Health Research. 2010;20:173643.

4. Tracy SJ. Qualitative quality: eight «big-tent» criteria for excellent qualitative research. Qualitative Inquiry. 2010;16:837-51.

5. Schou L, Høstrup H, Lyngsø EE, Larsen S, Poulsen I. Validation of a new assessment tool for qualitative research articles. Journal of Advanced Nursing. 2012;68:2086-94.

6. Critical Appraisal Skills Programme. Making sense of evidence. 2013. Tilgjengelig fra: https://caspuk.net/wp-content/uploads/2018/01/CASP-QualitativeChecklist-2018.pdf (nedlastet 30.04.2019). 